Pittsburgh University School of Law

Scholarship@PITT LAW

\title{
The Importance of Research on Race and Policing: Making Race Salient to Individuals and Institutions Within Criminal Justice
}

David A. Harris

University of Pittsburgh School of Law, daharris@pitt.edu

Follow this and additional works at: https://scholarship.law.pitt.edu/fac_articles

Part of the Civil Rights and Discrimination Commons, Criminal Law Commons, Law and Race Commons, Law and Society Commons, and the Law Enforcement and Corrections Commons

\section{Recommended Citation}

David A. Harris, The Importance of Research on Race and Policing: Making Race Salient to Individuals and Institutions Within Criminal Justice, 6 Criminology \& Public Policy 5 (2007).

Available at: https://scholarship.law.pitt.edu/fac_articles/115

This Article is brought to you for free and open access by the Faculty Publications at Scholarship@PITT LAW. It has been accepted for inclusion in Articles by an authorized administrator of Scholarship@PITT LAW. For more information, please contact leers@pitt.edu, shephard@pitt.edu. 


\title{
THE IMPORTANCE OF RESEARCH ON RACE AND POLICING: MAKING RACE SALIENT TO INDIVIDUALS AND INSTITUTIONS WITHIN CRIMINAL JUSTICE
}

\author{
DAVID A. HARRIS \\ University of Toledo College of Law
}

For many years, criminologists have directed research efforts at questions involving race and policing. And for just as many years, many criminal justice professionals-principally police officers and their leaders-have not welcomed this work. Based on their own experience, they feel that they understand the effect of race on police work better than most people, and certainly better than academics who spend their time doing research on law enforcement. The public debate over racial profiling, in which African-Americans and members of other minority groups say they have become targets of police over-enforcement, makes a good example. Police say that any extra enforcement effort that officers use against minorities results from common-sense application of probabilities, given who gets arrested everyday. For police officers themselves and their organizations, the attention researchers have given to an issue like profiling translates into an automatic accusation of racism. That is, asking questions about profiling in the context of research becomes equivalent, for many officers, to indicting the law enforcement profession as whole, or an individual police department, or perhaps some particular group of officers, as racist. And right now, in our society, there are few stronger epithets than "racist."

Take Marshall Frank. Frank served on the Miami-Dade police force for almost 30 years, retiring as a captain. When the racial profiling issue became prominent in the American media, Frank wrote an essay explaining the police perspective on the problem. Suppose, he said, that a police officer patrolling a predominantly white residential neighborhood spotted a car driving through the area. Two black males-one the driver, the other a front-seat passenger-occupy the vehicle. Nothing indicates that they or the vehicle have any relationship to any crime, either ongoing or planned, and the driver operates the vehicle no worse than the average driver would. Should the police officer follow the car, and when the officer spots some small traffic infraction, pull the vehicle over and use the occasion as an opportunity to find out what business the two men have in the neighborhood? Frank answers with an unequivocal yes. "Label me a 
racist if you wish, but the cold fact is that African Americans comprise [sic] 12 percent of the nation's population, but occupy nearly half of the state and federal prison cells. African Americans account for 2,165 inmates per 100,000 population, versus 307 for non-Hispanic whites and 823 for Hispanics" (Frank, 1999). This means, says Frank, that AfricanAmericans commit most of the serious crime, and until something changes radically, police should - they must - use every tool at their disposal to focus more crime-fighting scrutiny on the most likely offenders-blacks (and to a lesser extent, Hispanics). The decision to focus more police energy on African-Americans comes from the facts, Frank implies. The police roam the streets of crime-ridden neighborhoods every day; officers know who gets arrested, and they know who serves time in jails and prison. Anyone accusing police of deciding to watch members of minority groups more closely for any reason other than these purely factual observations levels an unjust accusation of racism at police.

Frank's reaction typifies what one often hears from police. We know all about race, they say. We harbor no more prejudice than other average folks - in fact, probably less, because we work with so many people of different races all of the time. Our decisions do not have their origin in racism. We just target our resources where the facts point us in order to have maximum impact on public safety. You will probably "[1]abel me a racist," former Captain Marshall Frank says, but he, like many other police officers, believes that race is already a legitimate factor in the everyday work of police. And they believe that it is the disproportionate criminal behavior of minority groups that they consistently encounter and arrest that makes race a salient factor in police work.

Perhaps, then, it would surprise no one if some police leaders and officers did not welcome the type of research presented in this issue of Criminology \& Public Policy; they might see these excellent articles examining several important intersections between race and policing as yet another set of accusations of police racism. But nothing could be less true. The pieces that follow do indeed examine the crossroads of race and policing. But they do so not to blame the police but to force unexamined questions in this always complex and often fraught area into the foreground-that is, to make these issues salient and illuminate them for both police officers and police institutions. In their examination of misdemeanor marijuana arrests in New York City, Andrew Golub, Bruce D. Johnson, and Eloise Dunlap (2007) show the vast burden of arrests for smoking marijuana in public in New York City, a focal point of the NYPD's so-called "quality of life" policing, and by 2000, the most common misdemeanor arrest and fully $15 \%$ of all arrests in the city, fell on black and Hispanic citizens. When arrested for this offense, black and Hispanic defendants were more likely to endure pretrial detention, to be 
convicted, and to suffer incarceration than whites arrested for the same crime. Golub et al. ask whether "quality of life gains achieved in the last decade can be sustained while reducing the disproportionate burden" of these arrests on blacks and Hispanics.

Rod Brunson's (2007) examination of the direct and vicarious experiences of 40 young black men with police harassment and violence shows how the cost of this police conduct reinforces negative attitudes toward police in a population already inclined toward mistrust of, and dissatisfaction with, law enforcement. And in one of the latest studies on the issue of racial profiling, Geoff Alpert, Roger Dunham, and Michael Smith (2007) find that the factors "with the largest impact on stopping black motorists include stops for equipment violations and investigative purposes," which is precisely the type of discretionary police activity that has encouraged some in the black community to believe that they have become police targets. Alpert and his colleagues attempt to explain the "disparate pattern of searches" of black drivers as compared with white drivers, but they conclude that "[s]earches aside, black drivers fared less well than white or Hispanic drivers in most other measures of post-stop outcomes" despite the fact that blacks were "the least likely of the racial and ethnic groups to be found in possession of contraband following a search." This result replicates several other studies of "hit rates" in police searches (Harris, 2002). The bottom line is that research into race and policing can still teach everyone in our society, especially police officers and their institutions, much that they do not know about how race plays a role in law enforcement. For everything that police, both individually and collectively, think they know about this topic, there is much more that they do not know. And what they do not know must begin with a discussion of how race may influence individual actions within the justice system.

\section{WHAT COGNITIVE PSYCHOLOGY CAN TELL US ABOUT RACE AND CRIMINAL JUSTICE: WHY UNCONSCIOUS ATTITUDES MAY MATTER MOST}

Researchers in the field of cognitive psychology have probed the roots of racial bias for some time. Their findings can do much to help us understand the real dangers of racism when it infects policing, as well as where racism originates and how it becomes activated in most people. In the United States, the societal acceptability of racism has changed dramatically in the last 50 years. In 1957, one would commonly find racists attitudes expressed openly, and few Americans would take exception to it. "Good people" might use racial and ethnic slurs as standard modes of 
expression in any "polite" conversation. Today, most people would hesitate to use such epithets or to judge whole racial or ethnic groups openly based on derogatory stereotypes. Moreover, the change in attitude goes beyond just what people are willing to say aloud. Most Americans feel that it is simply wrong to harbor racial prejudices and to act on them; most think that they do not have, or act on, these disfavored attitudes. At any rate, these represent the feelings and attitudes about race and ethnicity that most people would both express when asked, and would sincerely believe that they themselves have. But the work of cognitive psychologists shows us something both different and more complicated. Those antiracism views may, indeed, truly represent what most people think-consciously. But the data show that most people harbor racial and ethnic biases on the unconscious level. These unconsciously held biases operate independent of any consciously held beliefs and (perhaps obviously) outside the awareness of those who hold them (Greenwald and Banaji. 1995). Nevertheless, they influence our actions in important ways. We must therefore confront not only open bigotry, now stigmatized and therefore thankfully relatively rare, but also unconscious biases if we wish to truly face up to the problems at the junction of race and law enforcement.

Almost 20 years ago, Patricia Devine's study (1989) of the automatic and controlled aspects of stereotypes and prejudice examined this territory. Automatic processes, Devine argued, "involve the unintentional or spontaneous activation of some well-learned set of associations or responses .. . They do not require conscious effort and appear to be initiated by the presence of stimulus cues in the environment ... In contrast, controlled processes are intentional and require the active attention of the individual." In her study of automatic and controlled processes, Devine's data supported two hypotheses: she proposed that both persons who tested as "high-prejudice" and persons who tested as "low-prejudice" would be (1) equally knowledgeable about the racial stereotypes tested and (2) likely to respond in ways consistent with the stereotype-that is, to exhibit "prejudice-like responses"-when given tasks that operated only at the automatic process level. In other words, both persons who held racially stereotypical or prejudiced views, and those who did not. responded to tasks in prejudiced ways when they acted automatically, without conscious effort. Furthermore, Devine reported, the data suggested that "when automatically accessed the stereotype may have effects that are inaccessible to the subject. Thus, even for subjects who honestly report having no negative prejudices against Blacks, activation of stereotypes can have automatic effects that if not consciously monitored produce effects that resemble prejudiced responses." In a nutshell, then. Devine and other researchers who have followed her have shown that, regardless of one's conscious beliefs. deeply implanted racial and ethnic prejudices 
and stereotypes can become the basis for anyone's actions, and this happens even in those persons who do not consciously hold those beliefs and consider them undesirable and wrong.

As to the importance of unconscious bias, few examples speak as loudly as the Implicit Association Test (IAT), developed by Anthony Greenwald et al. (1998). The IAT grows from a simple but important insight: The human mind connects ideas it sees as related much more quickly than those it views as unrelated. Researchers measure the time it takes subjects to sort positive and negative word pairings associated with African-Americans and European-Americans, and these measurements indicate the "automatic preference" the subject has for each race. More than $80 \%$ of all subjects who have taken the test, whatever their race, have "pro-white associations," including half of the African-American test subjects (Gladwell, 2005). What makes research using the IAT such an important source of insight is that it lays bare the essential but often ignored issue in policing: racial biases inhabit the unconscious and can emerge without our awareness, and even despite our consciously held, positive attitudes concerning members of minority races and race relations. The IAT thus challenges in a direct way the oft-heard law enforcement attitude that welcomes neither research nor remedial measures regarding policing and race, because (as police say) they do not hold racist beliefs. The IAT shows that nearly everyone-not just police-harbors racially biased attitudes, and this is no less true just because one's conscious beliefs stand in opposition to racism. Those beliefs remain all to the good, but they do not change the fact that unconscious racial attitudes may influence the ways we behave. For people like police officers who claim (probably correctly) to have more frequent contacts with racial minorities than most other citizens do, the IAT looms large. And because police officers have the unique and vital professional responsibility for enforcing the rules in our society in a fair and even-handed way, the possibility that unconscious biases may emerge and influence what they do takes on great significance.

Greenwald et al. (1998) at the University of Washington used the IAT to show how hidden biases operated outside of conscious awareness, and even in contravention to stated non-prejudiced attitudes. First, they tested well-established positive and negative associations (flowers are pleasant, insects are unpleasant) and found that the IAT measured the differences in implicit associations well. They also showed that the IAT also measured implicit ethnic and racial biases well, despite the fact that the experimental subjects denied the presence of these biases and seemed to hold no explicit beliefs consistent with the implicit biases. Anyone interested in the effects of race in the justice system should note this last point well: The IAT seems to "resist masking by self-presentation strategies. That is, the implicit association method may reveal attitudes and other automatic 
associations even for subjects who prefer not to express those attitudes ... the IAT may indeed implicitly reveal explicitly disavowed prejudice." Combining a good news/bad news report with the understatement characteristic of writing in scientific journals, the researchers call their findings "encouraging in regard to the usefulness of the IAT" but "discouraging in indicating the pervasiveness of unconscious forms of prejudice." The presence of these implicit biases despite explicit disavowals of biased attitudes, and their operation outside of the awareness of subjects, has profound implications for the criminal justice system. Given the strong consensus about these facts among cognitive psychologists and others who study these matters, every actor in the criminal justice system would likely run at least some risk of acting under the influence of racial or ethnic biases in some aspect of his or her work. And this would happen without the actor knowing it; in fact, it would happen even in opposition to the actor's heartfelt beliefs and intentions. One could not describe these bias-infected actions as intentional; far from it. Yet the injuries that racial or ethnic minorities might incur as a result of those actions does not vary depending on whether the harm was intentional.

The possibility of biased-based damage extends well beyond the actions of police officers. For example, lay people serve as jurors. In that context, the existence of implicit racial or ethnic biases, hidden from the awareness of jurors, could influence critical decisions to the disadvantage of minority defendants. Sommers and Ellsworth (2001) studied these possibilities by exposing mock jurors to fictional narratives of trials. Years ago, white jurors would commonly exhibit open anti-black sentiments. Now, most white Americans consciously embrace an egalitarian perspective on questions of race, despite the existence of the implicit biases they may harbor unconsciously. The common wisdom had therefore been that, in trials without explicit racial issues, white jurors would be less likely to exhibit bias. Sommers and Ellsworth hypothesized that, on the contrary, trials without explicit racial issues would allow jurors' unconscious biases to influence what they decided; making the racial issues explicit, and thus salient to the jurors, would put the racial issue in the foreground and call forth jurors' explicit motivations to act without bias. In an earlier study, Sommers and Ellsworth (2000) had exposed mock jurors to trial narratives involving both white and black defendants in interracial crimes. In all of these narratives, the jurors learned the race of the defendant-sometimes black, sometimes white. But in some narratives, the researchers manipulated an aspect of the story to explicitly raise awareness of the racial identity of the defendant. Other than these details, the narratives did not differ. The results showed that, when the researchers had not made race explicitly salient, the proportion of white mock jurors voting to convict rose a statistically significant amount-from $73 \%$ to $87 \%$; the white jurors 
described the black defendant as significantly more dangerous than the white defendant and generally more crime prone. Sommers and Ellsworth's 2001 study supported these findings. They found that white mock jurors were equally likely to convict black and white defendants when the narratives put a special emphasis on race. But when the narrative revealed but did not emphasize race, the conviction rate of white and black defendants diverged: the white jurors convicted the white defendant $70 \%$ of the time but the black defendant $90 \%$ of the time.

Thus, the impact of implicit or hidden racial bias emerges as important, perhaps even determinative of verdicts, when found in jurors. But even this significant type of harm may pale in comparison with the effect implicit bias may have when police officers make decisions on the use of force. In a significant piece of research, Joshua Correll and colleagues (2002) examined how implicit biases might influence a police officer's most vital decision: whether or not to shoot a person who might be threatening the officer with a deadly weapon. In their experiment, a subject, in the role of police officer, is confronted with an on-screen simulation presenting an ambiguous situation: he comes upon a male in a crouching position, holding an object that could be a gun. The officer must react quickly, by either shooting the man or not. Race and ethnicity, it turns out, helps the officers "disambiguate" the unclear situations they face. They must react almost instantaneously to a situation that, by its nature, does not give the officer all of the information necessary for the officer to tell whether deadly danger exists, and the mind may use hidden racial biases to fill in the blanks.

This caused the researchers to wonder, in cases such as that of Amadou Diallo, the African immigrant killed by New York police in 1999 when he reached into his pocket for his wallet, whether 'the officers' decision to fire was influenced by the stereotypic association between African Americans and violence." To investigate this possibility, the simulation to which Correll and colleagues exposed their experimental subjects required them to make "a behavioral shoot/don't shoot decision," just as a police officer would. The subjects saw the image of a man standing against a background-an office, a corridor in a shopping mall, a courtyard of an apartment building. Half the men in the images were black, and half were white. In each image, the man has an object in one of his hands: either a silver or black gun, or a "non-gun" (an aluminum can, a silver camera, a black cell phone, or a black wallet). The men in the images appeared in five standard poses. Subjects reacted by hitting buttons labeled "shoot" or "don't shoot." The researchers recorded and compared the reaction times for each image the subjects saw, and in different phases of the experiment increased the time pressure (by showing the images more rapidly) and the 
stakes (by increasing or decreasing the rewards received by the participants according to how many situations they judge correctly and incorrectly). Subjects decided to shoot more quickly and more accurately (accuracy judged in terms of whether the man actually had a weapon) if the man in the image was black, and they decided not to shoot more quickly and more accurately if the target was white. This, Correll and colleagues say, means the perceived race or ethnicity can "influence a behavioral judgment with serious consequences for both the target and the shooter." Further experimentation showed that there was a stronger "Shooter Bias" among those who believed that there exists in the United States a robust stereotype of African-Americans as aggressive and violent, and that the race of the experimental subject did not have any effect on outcomes. The importance of the study, of course, can easily be understood in reverse. Regardless of his or her race or ethnicity, a police officer confronted with an ambiguous and potentially life-threatening situation will make the mistake of shooting an unarmed (and thus actually nonthreatening) black rian more often than the mistake of shooting an unarmed white man; officers will also make the mistake of not shooting an armed (and thus actually dangerous) white man more often than the mistake of not shooting an armed black man. Race and ethnicity operating at an unconscious level can, it turns out, have incredibly significant effects on police behavior, perhaps making the difference between life and deathnot only for the citizen but for the officer.

All of this may seem tremendously disheartening for anyone interested in the improvement of race relations in the United States generally and in long-term possibilities for changing the way that race influences police officers and policing. If racial and ethnic bias operates at such a deep unconscious level that it could influence police officers without their having any awareness of this-indeed, on a level so deep that it may actually contradict their own conscious beliefs-what hope exists for addressing the influence of race in police work? Are we deluding ourselves to think that the influence of race and ethnicity on policing could actually change for the better?

\section{THE RESEARCH SUGGESTS A POSITIVE WAY FORWARD}

Fortunately, there are reasons to believe we can move in better, more fruitful directions. Some of the same research discussed here gives us concrete ways in which we might pursue positive change in terms of race and policing. And this brings us back around to the original question at the beginning of this essay. Why pursue research on race and policing? Does it have the potential to help things improve? Or are we, as many officers 
believe, better off without the social irritant of research and public inquiry into topics like racial profiling, because police officers "know" that they are not racists? The answer lies not in backing away from research on race and policing, but in making race salient by bringing it into the foreground through this research. We need to bring racial bias out of the hidden darkness of the unconscious and into the light of our conscious attention. When we do that, we have a real chance to make a difference.

We can begin our consideration of this point with Sommers and Ellsworth's investigation of the biases of white jurors. Most Americans no longer accept holding, expressing, or acting upon overt racist attitudes, but unconscious biases may still influence jurors' actions. When they made lurking racial issues salient, Sommers and Ellsworth (2001) found, white jurors treated identically situated white and black defendants alike. When racial issues simply stayed in the background, biases asserted themselves in measurably higher conviction rates for black defendants as compared with identically situated white defendants. Pushing race into the foreground did not rouse racial biases; in fact, it motivated jurors to act consistently with their conscious, nonracist beliefs. Devine's findings (1989) echo this line of thought: By consciously directing one's thought processes, one can overcome the influence of the automatically engaged biases and stereotypes that inhabit the unconscious. This takes time, effort, and attention, Devine warns, but those who express "low-prejudice" frames of reference can make this happen.

Other research suggests methods by which this could be accomplished. Greenwald and Dasgupta (2001) report that exposure of their subjects to pictures of admired blacks and disliked whites prior to the IAT influenced the degree of implicit bias detected by the test. To some degree contradicting Devine's finding (1989) that reducing prejudice takes purposeful, conscious effort, Greenwald and Dasgupta found that showing their subjects' images of admirable black persons and despised white ones significantly weakened automatic pro-white attitudes-both right after seeing the images and for 24 hours afterward. In a similar vein, research by Rudman et al. (2001) supports the claim that training designed to address racial and ethnic prejudice can help reduce both conscious and unconscious biases. The Rudman et al. study showed greatly reduced bias, both explicit and implicit, against blacks when subjects enrolled in a seminar on "prejudice and conflict." Thus, Rudman and colleagues make a reasonable case for the effectiveness of properly-constructed cultural competency and diversity training. And another study (Blair et al., 2001) claims that the use of counter-stereotypic-controlled mental imagery "produced substantially weaker implicit stereotypes" compared with various control groups. The upshot of all of this is just as significant as the presence of unconscious racial and ethnic biases: Those biases do not seem to be immutable. On 
the contrary, an increasing amount of evidence suggests an unanticipated degree of malleability (Devine, 2001).

If this is so, there are reasons to welcome further research into race and policing. By attempting to confront, understand, and measure the possible influence of racial and ethnic bias in policing, the question of race remains salient to the policing profession as a whole, as well as to particular organizations and individuals. All the research seems to point to the fact that awareness is the key to ferreting out or counteracting implicit or unconscious biases; by keeping racial questions on the agenda, research on race and policing can keep the race question up front, where it is most likely to help us do better on this issue-even as it attempts to answer particular substantive questions.

\section{A COMPELLING EXAMPLE: RACIAL PROFILING}

Research into racial profiling makes a particular compelling example of this process at work. As the quote from Captain Marshall Frank at the beginning of this essay shows, this work has not always left police leaders and officers happy; just raising the issue has been enough to anger many of them (Jackson, 1998). But the research itself and the changes it has brought to the law and the civic landscape in a number of places have provided positive benefits to police and to the communities they serve.

The key idea, as we learn from the cognitive psychology literature, is salience. When we make racial issues or messages salient to individualswhen we call their attention to it in one way or another-those individuals emerge better equipped to resist the unconscious pull toward racial bias that inhabits almost everyone. And perhaps making the issue of racial bias salient works not just at the individual level; the biggest benefits may exist at the institutional level. In other words, research and public scrutiny on the issue of racial bias may have at least as important an impact on institutions, such as police departments and other law enforcement agencies. as it does on individual police officers. We will likely see progress on racial issues on the individual level in police departments only if there is progress on the institutional level. It is on the level of institutional leadership that the commitment to addressing issues of racial bias either is or is not made. Without that leadership-level institutional commitment, individuals in the organization below leadership ranks will not feel any need to change or even think much about the issue. No commitment means no attempt to teach members of the department about the nature and effect of unconscious racial bias and how this might affect the way the individual officer does his or her job. In other words, individual change follows institutional change, or at least institutional commitment to change; institutional 
change creates the framework for what particular individuals may accomplish or learn that enables change to occur.

An example will illustrate this process. Beginning in the 1940s, the Supreme Court said that police forces must comply with the Fourth Amendment's prohibition of improper searches and seizures [Wolf v. Colorado, 338 U.S. 25 (1949)]. But in practice, police often did not follow this constitutional rule because no legal consequences followed disobedience (Franceschini, 1993). And so police felt free to obey the Fourth Amendment or ignore it as they chose. But this changed with the U.S. Supreme Court's decision in Mapp v. Ohio [367 U.S. 643 (1961)]. Under Mapp, if the police acted illegally - that is, contrary to the Fourth Amendment-in how they gathered evidence, the courts would exclude the evidence from trial. Exclusion of evidence substantially weakened most criminal cases; in cases involving possession of contraband, in which the contraband usually constituted the only evidence, exclusion generally ended the case. The exclusionary rule, as this principle is known, remains in effect today [Hudson v. Michigan, U.S. 126 S. Ct. 2159 (2006)].

Police officers, of course, tend not to like the exclusionary rule. By its nature-that is, as it is a rule requiring the exclusion of evidence-exclusion only becomes an issue of any consequence where the police have already seized evidence. And in most cases, this means that police have almost certainly arrested a guilty defendant. Officers feel that excluding the evidence of guilt, just because of some legal "technicality" concerning the way officers collected the evidence, does nothing but give the bad guy a "get out of jail free" card.

All of this becomes important when one asks what has happened to law enforcement since the seismic change of Mapp in 1961-from virtual freedom from Fourth Amendment limits to the sudden ability of the Fourth Amendment to "bite" when officers acted in disregard of its strictures. The exclusionary rule changed policing as a profession, and police departments as institutions, by forcing them to conduct themselves according to the Fourth Amendment for the first time. With real consequences attending police law breaking, police departments had to change. They had to have officers who understood the law and knew what to do in order to follow it in their cases. This precipitated a wholesale change. According to Samuel Walker (1993), the imposition of the exclusionary rule "stimulated wide-ranging reforms in the education, training, and supervision of police officers." For example, prior to the 1960 s, police recruits in Chicago received absolutely no training in the law of search and seizure; by the early 1980s, they received 14 hours of training on this subject (Orfield, 1992). The Chicago Police Department, as an institution, began to show officers that it mattered whether courts excluded the evidence in their cases because of Fourth Amendment violations. Officers received ratings, 
based in part on whether they had "lost" any cases through the suppression of evidence; suppression of evidence in two big cases in any one year could put any chance of promotion out of reach. Monitoring systems also came into use, with reports required for supervisors any time evidence in a case was suppressed; internal review and discussion with supervisors would follow the report (Orfield, 1992).

The analogy to research on race and policing is far from perfect, but it is helpful nonetheless. The Mapp case, and its imposition of the exclusionary rule, made the Fourth Amendment salient to the police. It suddenly mattered, and police institutions responded; they had to. Research into race and policing can make race institutionally salient to police departments by repeatedly (and perhaps inconveniently) showing police and the public that racial issues can make a great deal of difference in police work. That is, the public notice and resulting pressure that the study of such issues will bring to bear on the subject has the potential to persuade, or perhaps force, police institutions to react and take action. To be sure, the effect is unlikely to be as drastic or as systemic as was the case with the imposition of the exclusionary rule; in that case, police departments that refused to pay attention to the legalities of search and seizure suffered the immediate consequences of lost cases, whereas if police ignore research, study, and public scrutiny on racial issues, most individual cases will continue through the system unaffected. Nevertheless, police institutions ignoring these issues would suffer an important loss of credibility and connection with the public, which would perceive the unresponsive agencies as, perhaps, adversaries, and certainly not as trusted partners. This, of course, could create a huge loss for any department, because most police agencies depend on getting the help and support of the public in order to do the difficult job of maintaining public order. The loss would loom even larger for the many police departments that subscribe to community policing, a philosophy of policing in which the support of the people police serve is not just preferable, but all important. Without it, community policing fails.

Once racial issues become institutionally salient, more police departments may move toward training, supervision, and policies that will encourage officers to think about the effect racial biases may have in their work. If putting race into the foreground, instead of having it lurk silently in the background, is the key to successfully addressing unconscious racial bias, departments can make this happen by putting officers in a position to know about these attitudes that all of us harbor, how they can affect police work, and how they can do something about it.

\section{DIVIDENDS FOR POLICE DEPARTMENTS}

But let us imagine a police agency with reluctant leadership-leadership 
that hesitates to confront difficult issues like racial profiling or other police practices possibly infected with racial bias. How might we explain to these leaders what their agencies can gain by taking on racial bias as an issue? Racial issues always prove volatile, provocative, and difficult, both outside and inside of police departments. Even assuming that confronting the possibility of racial bias in a police department constitutes a kind of abstract good in itself, police leaders may very well worry about the potential for great damage to a department's reputation and standing with the public. In order to take such risks, police leadership will want to see at least an equal possibility of some concrete gain.

There are at least two ways in which benefits will accrue to police departments if they make race salient to their officers. We might think of them as the rewards for making race salient, and both ultimately promise improved policing

First, by paying attention to the facts uncovered in research involving race and policing, police will learn important truths concerning how racially biased assumptions, hidden under the cloak of conventional police wisdom, actually hurt police efforts to conduct law enforcement in the most effective ways. For example, proponents of racial profiling-those who believe, as former Captain Marshall Frank does, that stopping, investigating, and searching black drivers and passengers in cars passing through white neighborhoods just makes sense-think that this increased police attention will yield higher dividends in terms of crime fighting. After all, using race or ethnic appearance this way will focus officers on the right people: those most likely to be involved in crime (Frank, 1999). But studies on the subject since the late 1990s reveal an answer that contradicts this conventional wisdom. Research on the question of who police search after traffic stops, and what those searches actually yield, found that the actual rate at which police officers succeed in finding contraband and making arrests-the "hit rate"-is actually lower among the AfricanAmericans and Latinos who are getting increased police attention because of their race than it is among whites (Harris, 2002). Whites, who are not the subjects of police attention based on race, actually have a higher hit rate than blacks, which is exactly the opposite of what proponents of profiling would predict. These results show the way toward more efficient policing for any police department willing to pay attention. A few departments have taken the research to heart, banning officers from asking drivers for permission to perform post-stop searches unless there is at least some reasonable, fact-based suspicion of a crime (Harris, 2002). Abandoning these so-called "consent searches" has now become official policy in these departments. In at least one well-known example, the leadership of the U.S. Customs Service ordered line officers to base searches on suspicious behavior and not on race or ethnicity and required these officers to 
get the permission of a supervisor for a search. As a result, the total number of searches dropped drastically, by almost two thirds in two years. At the same time, the rate of successful searches went up, roughly two and one-half times, and evened out across racial groups (Harris, 2002). By making past use of racial bias by Customs institutionally salient, the leadership of the Customs Service forced officers to confront racial biases and to do the job without them, resulting in more successful policing. At the same time, the agency greatly reduced the grave social costs associated with large-scale search programs that target minorities and that had succeeded only about $5 \%$ of the time.

Second, the desire and even the methods for putting racial bias at the forefront of the police agency mindset and police officer thinking can, itself, have substantial positive effects. For example, many researchers who have studied the racial profiling issue advise police departments to create task forces or committees. These bodies should include not just police officers who will implement the anti-profiling or profiling measurement strategies, but also community members, activists, police union representatives, and others. (Fridell et al., 2001; Harris, 2002; Ramirez et al., 2000) By including these diverse interests from the start of the process, police agencies can get these task forces to help them design the data collection systems often needed to study and act on racial profiling; the result, these authorities say, is often an improved process with better, clearer results in the end.

This is all to the good. But, in many places that have used such task forces, there have been other important benefits; they have not only rendered service on the racial profiling issue. Rather, many task forces have also become involved in the whole spectrum of race and policing issues and have provided important avenues for building bridges of trust and partnerships between police and the minority communities they serve (Harris, 2005). This has helped to replace the strain that has sometimes existed between police and minorities with at least the beginnings of relationships that can pay dividends over time.

A couple of examples illustrate the point. In Lowell, Massachusetts, the authorities formed a police/community task force to help the police department shape its effort to measure the possibility of racial profiling. But after the racial profiling study, the group remained together and began to work with the police department on related issues, most notably the misunderstandings that can crop up between police and new immigrants in their communities. Lowell has a particularly large immigrant community for a town its size. Many are from Cambodia, a place where (understandable) mistrust of authority runs deep; others come from countries in Africa, where corruption runs rampant and often includes police. Thus, many of these immigrants come to the United States and to Lowell 
with a deep distrust of law enforcement. The immigrants and the police officers on the task force in Lowell thus did a huge service to their community by using the task force meetings to educate each other in cultural and national practices vis-à-vis the appropriate ways to behave, and what to expect, when a police officer in the United States stops a car; this helps to avert potentially deadly misunderstandings (Harris, 2005). In some African countries, police learned, when an officer stops a car, it is customary for the driver to get out of the car and walk to the police vehicle; anything else is considered disrespectful. Immigrants learned that police in the U.S. expect drivers to stay inside their cars when stopped; anything else is considered aggressive and perhaps dangerous. The police learned that men in Africa often keep their identification and money in their socks, to avoid theft; immigrants learned that when American police see a man approaching a police officer's car and reaching toward his sock, they interpret this as an aggressive person about to pull a gun from an ankle holster.

In metropolitan Detroit, a group of community leaders, advocates, and law enforcement leaders convened as a task force in 1998 to discuss and work on the issue of racial profiling. The members of the group had varied interests and often dissimilar views of the racial profiling issue. Some (chiefly the community leaders and civil rights advocates) believed that police had to confront the problem and take action. Some of the law enforcement officials believed the problem did not exist at all; for them, racial profiling was nothing more than a media campaign to tar police officers with the brush of racism. But all of them agreed on the central importance of the community having trust in the police, and vice versa. Police in the group knew that, without the community's trust, they could not hope to make the towns and cities they served as safe as they could otherwise; as any police officer who understands community policing knows, public safety requires police and their communities to work together. And members of the community understood that they could not have safe, livable communities unless the police were their partners. Thus, although they could not (and ultimately did not) agree on what to do concerning racial profiling-the race-and-policing issue that brought them together in the first place-they all agreed on the importance of the police and community trusting in each other. Thus, the group's name: Advocates and Leaders for Police and Community Trust (ALPACT).

Despite its members' inability to agree on racial profiling, ALPACT has performed useful service on the issue. In 2000, ALPACT convened a conference on the topic for the entire Detroit metropolitan area; it was one of the largest such meetings held on the subject in the country. The group also served as a model for similar groups started in each of Detroit's police districts. But ALPACT's greatest utility came immediately after the events of September 11, 2001. In the Detroit area, home to the nation's largest 
Arab-American and Muslim populations, hate crimes and bias-based incidents against Muslims and Arabs began to spike. The law enforcement leaders who were members of ALPACT went to the group and asked for its support in addressing hate crimes, and ALPACT quickly agreed to put itself on record in the media. Members of the federal law enforcement community, charged with addressing violations of civil rights and investigating hate crimes, stood with members of ALPACT, including members from the Muslim and Arab communities in the area, and made clear that they would not stand for hate crimes and bias incidents on their collective beats. They asked community members to contact them directly if anything untoward took place, and they promised to act if notified. Then, in November 2001, just two months after the attacks, the Department of Justice announced that it would conduct interviews of 5,000 young Arab and Muslim men; because of its large Middle Eastern population, the Detroit area had one of the single largest contingents of potential interviewees of all cities in the country. These interviews, many law enforcement authorities knew, were potentially disastrous; they could alienate or frighten the very population, Middle Easterners, that would most likely possess potentially critical information. This could result in a catastrophic loss of intelligence, just when those trying to keep the country safe needed it the most. Once again, ALPACT became a key element of the city's response. Members of ALPACT came up with ideas to help these interviews take place with the least possible negative impact. Chief among them was that, instead of FBI agents showing up "cold" to conduct the interviews at the homes or businesses or jobs of the persons on the list, agents would instead send a letter to the person. The letter would state that the FBI wanted to talk to the recipient, that the recipient was under no obligation to do so, and that the recipient could hire counsel and have counsel present during the interview, and that the interview could take place in a location of the recipient's choosing. ALPACT members publicized the use of the letters with a media campaign. The result was the most successful interview effort in any city in the country. That is, a higher percentage of people on the list of interviewees in Detroit actually talked to the police in Detroit than in any other city in the country. Most credit this success to the efforts of ALPACT and its creative approach to the problem. And this would not likely have happened had the members of ALPACT not worked with each other, actively, for a considerable period of time, and learned to trust each other.

\section{CONCLUSION}

For the many social scientists and others who study and work with police departments, the utility of research on issues in which race and policing intersect seems obvious. But to police, this research, and the 
increase in public scrutiny that occasionally comes with it, does not always seem a service to the profession. But the fact is that much of what actually matters in terms of race and the way human beings think is largely hidden in the unconscious. These hidden facets of the human mind may remain invisible to us, but as the research of cognitive psychologists shows, they do not stay inactive, and can even influence our actions in ways we do not realize. Only making these hidden racial biases salient can help us to combat their influence. Work on racial bias or race and policing helps to do this, by forcing the institutions of policing to come to grips with these possibilities; the institutions, in turn, can help individual officers to confront these hidden biases as well.

\section{REFERENCES}

Alpert, Geoffrey, Roger Dunham, and Michael Smith

2007 Investigating racial profiling by the Miami-Dade police department: A multimethod approach. Criminology \& Public Policy. This issue.

Blair, Irene V., Jennifer E. Ma, and Alison P. Lenton

2001 Imagining stereotypes away: The moderation of implicit stereotypes through mental imagery. Journal of Personality and Social Psychology 81:828-841.

Brunson, Rodney K.

2007 "Police don't like black people": African-American young men's accumulated police experiences. Criminology \& Public Policy. This issue.

Correll, Joshua, Bernadette Park, Charles M. Judd, and Bernd Wittenbrink

2002 The police officer's dilemma: Using ethnicity to disambiguate potentially threatening individuals. Journal of Personality and Social Psychology 83:1314-1329.

Devine, Patricia G.

1989 Stereotypes and prejudice: Their automatic and controlled components. Journal of Personality and Social Psychology 56:5-18.

2001 Implicit prejudice and stereotyping: How automatic are they? Journal of Personality and Social Psychology 81:757-759.

Frank, Marshall

1999 Racial profiling: Better safe than sorry. Miami Herald (October 19).

Franceschini, Remo

1993 A matter of honor: One cop's lifelong pursuit of John Gotti and the mob. New York: Simon \& Schuster.

Fridell, Lorie, Robert Lunney, Drew Diamond, and Bruce Kobu

2001 Racially biased policing: A principled response. Washington, D.C.: Police Executives Research Forum.

Gladwell, Malcolm

2005 Blink: The Power of Thinking Without Thinking. New York: Little, Brown. 
Golub, Andrew, Bruce D. Johnson, and Eloise Dunlap

2007 The race/ethnicity disparity in misdemeanor marijuana arrests in New York City. Criminology \& Public Policy. This issue.

Greenwald, Anthony G. and Mahzarin R. Banaji

1995 Implicit social cognition: Attitudes, self-esteem and stereotypes. Psychological Review 102:4-27.

Greenwald, Anthony G., Debbie E. McGhee, and Jordan L. K. Schwartz

1998 Measuring individual differences in implicit cognition: The Implicit Association Test. Journal of Personality and Social Psychology 74:1464-1480.

Greenwald, Anthony G. and Nilanjana Dasgupta

2001 On the malleability of automatic attitudes: Combating automatic prejudice with images of admired and disliked individuals. Journal of Personality and Social Psychology 81:800-814.

Harris, David A.

2002 Profiles in Injustice: Why Racial Profiling Cannot Work. New York: The New Press.

2005 Good Cops: The Case for Preventive Policing. New York: The New Press.

Jackson, Robert L.

1998 Push against bias in traffic stops arrested. Los Angeles Times (June 1).

Orfield, Myron W.

1992 Deterrence, perjury, and the heater factor: An exclusionary rule in the Chicago criminal courts. University of Colorado Law Review 63:75-83.

Ramirez, Deborah, Jack McDevitt, and Amy Farrell

2000 A resource guide on racial profiling data collection systems: Promising practices and lessons learned. Washington, D.C.: U.S. Department of Justice.

Rudman, Laurie A., Richard D. Ashmore, and Melvin L. Gary

2001 "Unlearning" automatic biases: The malleability of implicit prejudice and stereotypes. Journal of Personality and Social Psychology 81:856-868.

Sommers, Samuel R. and Phoebe C. Ellsworth

2000 Race in the courtroom: Perceptions of guilt and dispositional attributions. Personality and Social Psychology Bulletin 26:1367-1379.

2001 White juror bias: An investigation of prejudice against black defendants in the American courtroom. Psychology, Public Policy, and Law 7:201-229.

Walker, Samuel

1993 Taming the System: The Control of Discretion in Criminal Justice, 19501990. New York: Oxford University Press.

David A. Harris is the Eugene Balk Professor of Law and Values at the University of Toledo College of Law. Harris has authored numerous studies of racial profiling. His 2002 book, Profiles in Injustice: Why Racial Profiling Cannot Work, was the first to demonstrate that using race or ethnicity as part of a profile hurts police efforts to catch criminals. His work has become the basis for laws enacted against racial profiling across the U.S. Harris's 2005 book, Good Cops: The Case for Preventive Policing 
explains how police can reduce crime effectively and still respect the civil rights and dignity of citizens. He has presented his research to the U.S. Senate, many state legislatures, and academic bodies, and he works frequently as a trainer for police, judges. lawyers. and citizens groups. 


\section{HARRIS}

